ISSN: 2338-4328 (Print), ISSN: 2686-2646 (Online)

Available online at: https://sultanist.ac.id/index.php/sultanist

\title{
EFEKTIFITAS DAN KONTRIBUSI LABA BADAN USAHA MILIK DAERAH (BUMD) TERHADAP PENDAPATAN ASLI DAERAH (PAD) KABUPATEN INDRAGIRI HULU
}

\author{
Heriasman $^{1)}$, Suwaji ${ }^{2)}$ \\ 1,2 Program Studi Manajemen STIE Indragiri Rengat \\ J1. R. Soeprapto No 14. RengatTelp (0769) 21019 KodePos: 29312 \\ *Correspondence email: heriasman@ @stieindragiri.ac.id, suwaji@stieindragiri.ac.id.
}

\begin{abstract}
Abstrak
Badan Usaha Milik Daerah (BUMD) memiliki peran dalam mengisi Pendapatan Asli Daerah (PAD) melaui pos pendapatan daerah lainnya yang sah. Pos ini merupakan pendapatan yang didapat dari bagian laba penyertaan modal yang dilakukan pemerintah daerah/kabupaten dalam upaya peningkatan dan pengembangan. Penelitian ini dilakukan pada BUMD di Kabupaten Indragiri Hulu. Tujuan penelitian ini untuk menganalisis tingkat efektifitas, kontribusi dan pertumbuhan kontribusi BUMD terhadap PAD serta permasalahan manajemen BUMD. Data penelitian di kumpulkan dengan teknik dokumentasi dan teknik wawancara terstruktur. Analisis data menggunakan analisis deskriptif. Hasil analisis menunjukkan, target PAD belum sepenuhnya dapat direalisasikan, secara rata-rata pertumbuhan realisasi PAD lebih kecil dari target, target rasio efektifitas laba BUMD masuk dalam kategori Kurang Efektif. Kontribusi laba BUMD terhadap PAD masuk pada kategori sangat kurang, dan laba BUMD memberikan kontribusi terkecil terhadap PAD bila di bandingkan dengan komponen-komponen PAD lainya. solusi dari permasalahan manajemen BUMD Kabupaten Indragiri Hulu adalah memperbaiki manajemen internal agar dibuat lebih ramping dan adaftif sesuai dengan kebutuhan, menyikapi dengan bijak ancaman dari eksternal dengan memberikan perhatian pada perbaikan mutu produk dan jasa serta fokus dalam mengembangkan usaha agar BUMD mampu tumbuh dan berkembang dengan membuat proyeksi yang jelas dan serius dalam menjaga keberlanjutan usaha BUMD
\end{abstract}

Kata kunci: Efektifitas, Kontribusi, Manajemen, BUMD, PAD

\section{EFFECTIVENESS AND PROFIT CONTRIBUTION OF REGIONAL OWNED BUSINESS ENTITIES (BUMD) TO REGIONAL ORIGINAL INCOME (PAD) INDRAGIRI HULU REGENCY}

\begin{abstract}
Regional-Owned Enterprises (BUMD) have a role in filling Regional Original Income (PAD) through other legal regional income posts. This post is the income derived from the share of capital participation made by the regional / district government in an effort to increase and develop. on BUMD in Indragiri Hulu Regency. The purpose of this study is to analyze the level of effectiveness, contribution and growth of BUMD's contribution to $P A D$ and BUMD management problems. The research data was collected using documentation techniques and structured interview techniques. Data analysis used descriptive analysis. The results of the analysis showed that the target was PAD has not been fully realized, on average, the growth in realization of PAD is smaller than the target, the target ratio for BUMD's profit effectiveness is in the Less Effective category. It is compared with other PAD components. the solution to the management problems of Indragiri Hulu Regency BUMD is to improve internal management so that it is made leaner and more adaptive according to needs, respond wisely to external threats by paying attention to improving the quality of products and services and focusing on developing businesses so that BUMDs are able to grow and develop by making clear and serious projections in maintaining the sustainability of BUMD businesses.
\end{abstract}

Keywords: Effectiveness, Contribution, Management, BUMD, PAD 


\section{PENDAHULUAN}

Dalam pelaksanaan otonomi daerah, pemerintah daerah dalam hal ini mulai dari pemerintah Kabupaten, pemerintah daerah kabupaten/kota memperoleh kewenangan yang luas dalam mengembangkan dan mengelola daerahnya dan dituntut kemandiriannya terutama yang berkaitan dengan upaya peningkatan Pendapatan Asli Daerah (PAD). Hal utama yang menunjukkan suatu daerah otonom mampu berdiri sendiri dalam pembangunannya terletak pada kemampuan keuangan daerah tersebut untuk menggali sumber- sumber keuangan sendiri dan mengurangi ketergantungan terhadap pemerintah pusat menjadi seminimal mungkin. Didalam UU No. 33 Tahun 2004 telah diatur bahwa pemerintah daerah dapat meningkatkan pendapatan asli daerah dalam rangka miningkatkan kapasitas fiskal dengan melakukan optimalisasi sumber-sumber Pendapatan Asli Daerah (PAD) dengan meningkatkan pajak daerah, retribusi daerah, hasil pengelolaan kekayaan daerah yang di pisahkan dan PAD lain-lain yang sah serta mengoptimalisasikan bagi hasil pajak diharapkan dapat meningkatkan kemandirian daerah. Pendapatan Asli Daerah (PAD) merupakan salah satu indikator dalam mengukur pertumbuhan ekonomi suatu daerah karena didalam PAD terdapat komponen pembentuk pertumbuhan ekonomi yang mencerminkan indikator dari PDRB, semakin besar pendapatan asli daerah maka dapat dijadikan sebagai tolok ukur bahwa pertumbuhan ekonomi daerah tersebuat berada pada tingkatan yang baik. Dilihat dari sisi pendapatan, keuangan daerah yang berhasil adalah jika keuangan daerah mampu meningkatkan penerimaan daerah secara berkelanjutan seiring dengan perkembangan perekonomian di daerah tersebut tanpa memperburuk alokasi faktor-faktor produksi dan rasa keadilan dalam masyarakat serta dengan biaya untuk mendapatkan penerimaan daerah secara efektif dan efisien (Luigi, dkk 2017).

Sumber penerimaan daerah (PAD) salah satunya berasal dari laba Badan Usaha Milik Daerah (BUMD). Badan Usaha Milik Daerah (BUMD) merupakan usaha yang dimiliki oleh Pemerintah Daerah yang diharapkan memberikan kontribusi positif terhadap keuangan daerah, namun pada kenyataanya justru lebih banyak suntikan dana dari pemerintah daerah daripada keuntungan yang di dapat, kondisi tersebut menjadi beban bagi APBD, sehingga apa yang menjadi tujuan berdirinya BUMD adalah sebagai salah satu sumber pendapatan pemerintah daerah tidak tercapai (P2 LIPI, 2010). Kinerja Badan Usaha Milik Daerah (BUMD) belum optimal, sebagian besar BUMD di Indonesia belum memberikan kontribusi yang maksimal terhadap pertumbuhan perekonomian daerah (Kresno, 2010).

Kabupaten Indragiri Hulu merupakan satu dari 12 Kabupaten dan Kota yang ada di rpovinsi Riau. Hasil pengelolaan PAD Kabupaten Indragiri Hulu dapat dilihat melalui target dan realisasi penerimaan PAD Kabupaten Indragiri Hulu selama periode tahun 2014-2019 sebagai berikut:

Tabel 1.

Target dan Realisasi Pendapatan Asli Daerah Kabupaten Indragiri Hulu Tahun 2014 - 2019.

\begin{tabular}{|c|c|c|c|c|}
\hline \multirow[b]{2}{*}{ Tahun } & \multicolumn{4}{|c|}{ PAD } \\
\hline & Target (Rp) & $\%$ & Realisasi (Rp) & $\%$ \\
\hline 2014 & 62.409 .888 .691 & & $111.827 .898 .830,96$ & \\
\hline 2015 & 103.357 .697 .903 & 0,66 & $125.148 .593 .066,93$ & 0,12 \\
\hline 2016 & 89.808.068.044 & $-0,13$ & $98.845 .361 .438,48$ & $-0,21$ \\
\hline 2017 & 164.442 .903 .083 & 0,83 & $159.665 .857 .817,46$ & 0,62 \\
\hline 2018 & 106.679 .031 .058 & $-0,35$ & $111.900 .731 .074,40$ & $-0,30$ \\
\hline 2019 & 115.670 .377 .495 & 0,08 & $118.978 .915 .053,47$ & 0,06 \\
\hline $\begin{array}{l}\text { Rata- } \\
\text { rata }\end{array}$ & 10.652 .097 .760 & 0,22 & $1.430 .203 .244,50$ & 0,06 \\
\hline \multicolumn{5}{|c|}{$\begin{array}{l}\text { (Sumber : Dispenda Kabupaten Indragiri Hulu, data } \\
\text { diolah) }\end{array}$} \\
\hline $\begin{array}{r}\text { Se } \\
2019 \mathrm{tz}\end{array}$ & $\begin{array}{l}\text { ra rata-rata } \\
\text { get dari PAD }\end{array}$ & $\begin{array}{l}\text { lari } \mathrm{t} \\
\text { Kabur }\end{array}$ & $\begin{array}{l}\text { un } 2014- \\
\text { en Indragiri }\end{array}$ & \\
\hline
\end{tabular}

Copyright (C) 2021, SULTANIST: Jurnal Manajemen dan Keuangan 
Hulu tumbuh sebasar 22\%, sedanngkan realisasi PAD secara rata-rata hanya tumbuh $6 \%$. Pertumbuhan realisasi PAD Kabupaaten Indragiri Huku lebih kecil dari target yang direncanakan dan ada kecenderungan penurunan pada realisasi PAD terutama pada kurun waktu 20182019 yang lebih rendah dari tahun 2017, kondisi tersebut bias saja menjadi masalah bagi daerah dimana kebutuhan pendanaan pembangunan daerah yang cenderung meningkat dari tahun ketahun tidak dapat diimbangi dengan peningkatan keuangan daerah terutama yang bersumber dari Pendapatan Asli Daerah (PAD), hal tersebut patut menjadi perhatian dan bahan kajian karena realisasi Pendapatan Daerah (PAD) merupakan salah satu kriteria untuk mengetahui kemampuan daerah dalam mengatur dan mengurus rumah tangganya dalam bidang keuangan daerah yang berarti juga untuk mengetahui kemampuan daerah dalam melaksanakan otonomi daerah.

Dalam pelaksanaan pembangunan perekonomian daerah di Kabupaten Indragiri Hulu, keberadaan BUMD diharapkan memberikan kontribusi terhadap terhadap PAD berupa bagian laba penyertaan modal yang masuk di pos hasil kekayaan daerah yang dipisahkan. Peran pemerintah daerah sangat penting dalam pengembangan BUMD, karena lewat pemerintah daerah BUMD mendapatkan penyertaan modal yang dapat digunakan untuk pengembangan BUMD itu sendiri. BUMD sebagai pelaku usaha yang berhubungan dengan manajemen kekayaan/asset daerah yang bertanggungjawab untuk mengembangkan kekayaan daerah yang dimiliki) melalui pendapatan dan laba yang dihasilkan diharapkan mampu berperan aktif sebagai bagian/komponen Pendapatan Asli Daerah (PAD) dalam menyokong pertumbuhan dan pembangunan daerah.

Tujuan dari penelitian ini adalah untuk mengetahui efektifitas Badan Usaha Milik
Daerah (BUMD) Kabupaten Indragiri Hulu dalam memberikan kontribusi terhadap Pendapatan Asli Daerah (PAD) Kabupaten Indragiri Hulu, dan menemukan permasalahan-permasalahan pengelolaan BUMD dan memberikan solusi-solusi untuk perbaikan kinerja BUMD dimasa yang akan datang.

\section{LANDASAN TEORI}

Badan Usaha Milik Daerah (BUMD) berdasarkan Pasal 1 angka 40 Undangundang No. 23 Tahun 2014 adalah badan usaha yang seluruh atau sebagian besar modalnya dimiliki oleh daerah, dan sebagaimana disebutkan dalam Pasal 6 Peraturan Pemerintah No. 54 Tahun 2017, BUMD memiliki karakteristik sebagai berikut: a) Badan usaha didirikan oleh pemerintah daerah; b) Badan usaha dimiliki oleh 1 (satu) pemerintah daerah, lebih dari 1 (satu) pemerintah daerah, (satu) pemerintah daerah dengan bukan daerah, atau lebih dari 1 (satu) pemerintah daerah dengan bukan daerah; c) Seluruh atau sebagian besar modalnya merupakan kekayaan daerah yang dipisahkan; d) Bukan merupakan organisasi perangkat daerah; dan e) Dikelola dengan menggunakan kelaziman dalam dunia usaha.

Dalam susunan PAD, BUMD memiliki peranan dalam mengisi pos Pendapatan Daerah Lainnya yang Sah. Pos ini merupakan pendapatan yang didapat dari bagian laba penyertaan modal yang dilakukan pemerintah daerah/kabupaten dalam upaya peningkatan dan pengembangan (Kasmir; 2010). Keberadaan perusahaan daerah (BUMD) adalah untuk mencari profit dalam bidang usahanya dalam rangka meningkatkan pendapatan asli daerah dari deviden yang disetorkan ke kas daerah, deviden yang diperoleh dari BUMD tersebut kemudian akan menjadi pendapatan pemerintah daerah yang akan meningkatkan kemampuan APBD dalam 
membiayai pembangunan daerah. Pembagian konsep BUMD yang berorentasi pada bisnis dan pelayanan pada masyarakat sebenarnya memilki beberapa konsekuensi, untuk BUMD yang berorentasi pada aspek bisnis diharapkan dapat memberikan keuntungan secara finansial. Sedangkan BUMD yang berorentasi pada pelayanan masyarakat diharapkan mampu memenuhi kebutuhan dan kepentingan masyarakat umum (Harahap dalam Yudho, 2014).

Permasalahan pengelolaan yang kompleks menyebabkan investasi perusahaan daerah tidak dapat dikelola dengan efektif (Andi, 2020). Kinerja Badan Usaha Milik Daerah (BUMD) belum optimal, sebagian besar BUMD diIndonesia belum memberikan kontribusi yang maksimal terhadap pertumbuhan perekonomian daerah (Kresno, 2010). Laba BUMD masih belum memberikan kontribusi yang signifikan terhadap pendapatan asli daerah, pendapatan asli daerah juga masih belum bisa memberikan pengaruh yang signifikan terhadap pertumbuhan ekonomi daerah (Haince, dkk. 2019). Pertumbuhan penerimaan Badan Usaha Milik Daerah (BUMD) mengalami fluktuasi, dan tingkat efektivitas penerimaan Badan Usaha Milik Daerah (BUMD) selama lima tahun terakhir pada kategori efektif, selanjutnya kontribusi penerimaan Badan Usaha Milik Daerah (BUMD) terhadap Pendapatan Asli Daerah (PAD) berada pada kategori sangat kurang (Nurmiati, dkk. 2019). Tingkat efisiensi BUMD termasuk kategori baik (Maskun, dkk. 2018). peningkatan penerimaan dari hasil pengelolaan kekayaan daerah dalam menunjang penerimaan daerah dengan cara Intensifikasi dan Ekstensifikasi dapat berjalan dengan efektif (Usman, dkk. 2015).

\section{METODE}

Penelitian ini menggunakan pendekatan deskriptif kuantitatif. Data yang dikumpulkan adalah data kuantitatif dan data kualitatif hasil wawancara kepada informan untuk mengetahui permasalahan-permasalahan pengelolaan Usaha Milik Daerah (BUMD). Analiasis mengenai efektifitas, kontribusi dan analisis pertumbuhan kontribusi BUMD menggunakan instrument sebagai berikut.

\section{Analisis Efektivitas.}

Perhitungan efektivitas digunakan untuk mengetahui keberhasilan BUMD dalam mencapai sasaran yang telah ditetapkan. Metode yang digunakan adalah Charge Performance Index (CPI). Adapun rumus menurut yang digunakan:

$$
C P I=\frac{\text { Realisasi Pemungutan }}{\text { Target Penerimaan }} \times 100 \%
$$

(sumber: Halim, 2014)

Nilai efektifitas dengan persentase besar, maka dapat dikatakan bahwa Manajemen BUMD efektif, dan sangat efektif bila dapat mencapai target seratus persen, demikian sebaliknya.

\section{Tabel 2 : Klasifikasi Nilai Efektivitas}

\begin{tabular}{cc}
\hline Persentase & Kriteria \\
\hline Di atas $100 \%$ & Sangat Efektif \\
$91 \%-100 \%$ & Efektif \\
$81 \%-90 \%$ & Cukup Efektif \\
$60 \%-80 \%$ & Kurang Efektif \\
Kurang dari $60 \%$ & Tidak Efektif
\end{tabular}

(Sumber : Halim 2014)

\section{Analisis kontribusi}

Analisis Kontribusi Badan Usaha Milik Daerah digunakan untuk mengetahui kontribusi dari penerimaan laba BUMD dalam mendukung pendapatan daerah. Analisis ini dihitung dengan cara membandingkan antara realisasi penerimaan dari laba BUMD dengan realisasi penerimaan Pendapatan Asli Daerah (PAD). Adapun rumus kontribusi :

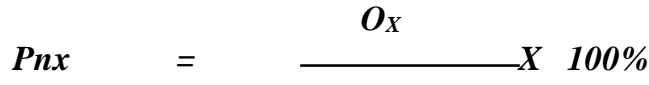


$Q_{Y}$

(Sumber : Halim, 2014))

Keterangan :

Pnx = Kontribusi penerimaan BUMD terhadap

PAD pada tahun tertentu

$\mathrm{QY}_{\mathrm{Y}} \quad=$ Jumlah penerimaan $\mathrm{PAD}$

$\mathrm{QX}_{\mathrm{X}} \quad=$ Jumlah penerimaan hasil

laba BUMD

Dengan membandingkan hasil analisis tersebut dari tahun ke tahun selama periode 2014-2019 akan diketahui kontribusi yang terbesar dan yang terkecil dari tahun ke tahun. Untuk menilai kriteria kontribusi dari laba BUMD dapat terlihat pada Tabel 2 :

Tabel 3 : Klasifikasi Kriteria Kontribusi

\begin{tabular}{cc}
\hline Klasifikasi Kontribusi & Kriteria \\
\hline $0,00 \%-10 \%$ & Sangat Kurang \\
$10,10 \%-20 \%$ & Kurang \\
$20,10 \%-30 \%$ & Sedang \\
$30,10 \%-40 \%$ & Cukup Baik \\
$40,10 \%-50 \%$ & Baik \\
Diatas 50\% & Sangat Baik
\end{tabular}

(Sumber : Haince, dkk. 2019)

\section{HASIL DAN PEMBAHASAN Laba BUMD}

Badan Usaha Milik Daerah (BUMD) dituntut untuk mampu menghasilkan keuntungan atau laba, semakin tinggi BUMD dalam memghasilkan laba berarti semakin baik dalam berkontribusi terhadap PAD yang berarti juga semakin baik perannya dalam memberikan sumbangan terhadap PDRB.

Tabel 4.

Target dan Realisasi Laba Badan Usaha Milik Daerah (BUMD) Kabupaten Indragiri Hulu

Tahun 2014 - 2019

\begin{tabular}{|c|c|c|c|c|}
\hline \multirow{2}{*}{ Tahun } & \multicolumn{3}{|c|}{ Laba Badan Usaha Milik Daerah } & \multirow[b]{2}{*}{$\%$} \\
\hline & Target $(\mathbf{R p})$ & $\%$ & Realisasi (Rp) & \\
\hline 2014 & 1.715 .046 .872 & & 1.847 .128 .110 & \\
\hline 2015 & 2.320 .402 .538 & 0,35 & 1.995 .009 .115 & 0,08 \\
\hline 2016 & 2.317 .471 .484 & $-0,0013$ & 1.191.287.190 & $-0,40$ \\
\hline 2017 & 1.657 .595 .771 & $-1,72$ & 1.657 .595 .771 & 0,39 \\
\hline 2018 & 1.657 .595 .771 & $-2,00$ & 1.651.113.295 & 0,00 \\
\hline 2019 & 1.657 .595 .771 & 0,00 & 1.238.995.948 & $-0,25$ \\
\hline Rata-rata & & $-0,67$ & & 0,037 \\
\hline
\end{tabular}

Secara rata-rata target laba BUMD Kabupaten Indragiri Hulu cenderung menurun atau rata-rata turun sebasar $67 \%$, dan hal tersebut senada dengan realisasi PAD yang secara rata-rata juga menurun atau tumbuh minus sebesar $3,7 \%$.

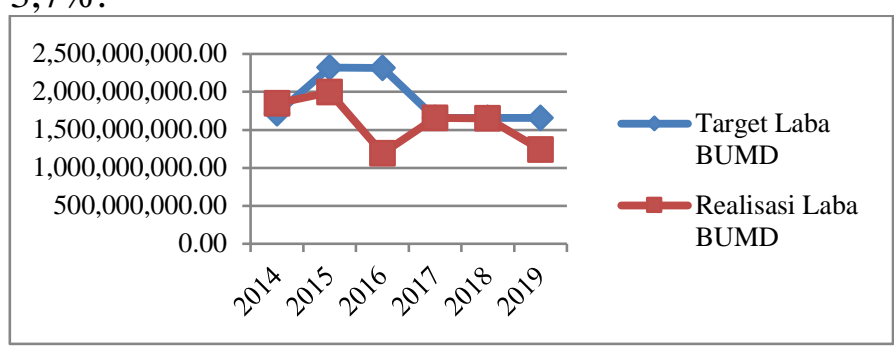

Gambar 1:

Target dan Realisasi Laba BUMD

Kabupaten Indragiri Hulu Tahun 2014 - 2019

Pada gambar 1 terlihat lebih jelas rencana dan capaian laba BUMD yang belum mampu memenuhi target yang diharapkan dan terlihat cenderung menurun.

\section{Efektivitas Laba Badan Usaha Milik Daerah}

Tingkat keberhasilan BUMD dalam mengangsilkan dapat dijadikan informasi dan evaluasi kinerja manajemen BUMD. Rasio efektifitas dimaksudkan untuk menilai sejauh mana efektifitas pengelolaan komponen pendapata asli daerah, khususnya komponen hasil pengelolaan kekayaan daerah oleh BUMD atau lebih ringkas disebut laba BUMD.

Tabel 5.

Rasio Efektivitas Laba Badan Usaha Milik Daerah Kabupaten Indragiri Hulu Tahun 20142019.

\begin{tabular}{|c|c|c|c|c|}
\hline \multirow[b]{2}{*}{ Tahun } & \multicolumn{2}{|c|}{ Laba Badan Usaha Milik Daerah } & \multirow{2}{*}{$\begin{array}{l}\text { Rasio } \\
\text { Efektivitas }\end{array}$} & \multirow[b]{2}{*}{ Keterangan } \\
\hline & Target (Rp) & Realisasi (Rp) & & \\
\hline 2014 & 1.715 .046 .872 & 1.847 .128 .110 & 1,077 & Sangat Efektif \\
\hline 2015 & 2.320 .402 .538 & 1.995 .009 .115 & 0,860 & Efektif \\
\hline 2016 & 2.317 .471 .484 & 1.191 .287 .190 & 0,514 & Tidak Efektif \\
\hline 2017 & 1.657 .595 .771 & 1.657 .595 .771 & 1,000 & Efektif \\
\hline 2018 & 1.657.595.771 & 1.651.113.295 & 0,996 & Efektif \\
\hline 2019 & 1.657 .595 .771 & 1.238 .995 .948 & 0,747 & Kurang Efektif \\
\hline Rata-rata & & & 0,74 & Kurang Efektif \\
\hline \multicolumn{5}{|c|}{$\begin{array}{l}\text { (Sumber : Bapenda Kabupaten Indragiri Hulu, Data } \\
\text { diolah) }\end{array}$} \\
\hline
\end{tabular}

Copyright (C) 2021, SULTANIST: Jurnal Manajemen dan Keuangan 
$7,4 \%$ persen atau masuk dalam kategori Kurang Efektif. Nilai rasio tertinggi dicapai pada tahun 2014 yaitu sebesar 1,077 atau $100,07 \%$ persen masuk dalam kategori Sangat Efektif, nilai tersebut dapat dicapai karena target yang ditetapkan pada tahun tersebut sebesar Rp. 1,7 miliar dapat direalisasikan sebesar Rp. 1,8 miliar. Nilai rasio terendah dicapai pada tahun 2016 sebesar 5,1 persen masuk pada kategori tidak efektif.

\section{Kontribusi Laba Badan Usaha Milik Daerah (BUMD) Terhadap PAD Kabupaten Indragiri Hulu \\ BUMD diharapkan berperan sebagai} salah satu sumber PAD di daerah, maka tentu saja BUMD dituntut agar lebih profesional dan lebih efisien dalam melaksanakan usahanya sehingga mampu berkontribusi secara nyata dalam kemajuan dan pertumbuhan ekonomi di daerah.

Tabel 6.

Pertumbuhan Kontribusi Laba BUMD Pendapatan Asli Daerah Kabupaten Indragiri Hulu, Tahun 2014 - 2019.

\begin{tabular}{cccc}
\hline Tahun & Realisasi PAD & $\begin{array}{c}\text { Realisasi Laba } \\
\text { BUMD }\end{array}$ & $\begin{array}{c}\text { Kontribusi } \\
\text { Laba }\end{array}$ \\
\hline 2014 & 111.827 .898 .830 & 1.847 .128 .110 & 0,017 \\
2015 & 125.148 .593 .066 & 1.995 .009 .115 & 0,016 \\
2016 & 98.845 .361 .438 & 1.191 .287 .190 & 0,012 \\
2017 & 159.665 .857 .817 & 1.657 .595 .771 & 0,010 \\
2018 & 111.900 .731 .074 & 1.651 .113 .295 & 0,015 \\
2019 & 118.978 .915 .053 & 1.238 .995 .948 & 0,013 \\
\hline Rata- & & & 0,014 \\
\hline
\end{tabular}

(Sumber : Bapenda Kabupaten Indragiri Hulu, Data diolah)

Rata-rata kontribusi laba BUMD terhadap Pendapatan Asli Daerah (PAD) selama periode 2014 - 2019 secara rata-rata sebesar $1,4 \%$ persen, nilai ini menunjukkan bahwa kontribusi laba BUMD masuk pada kategori sangat kurang, untuk memperjelas gambaran mengenai pertumbuhan kontribusi laba BUMD terhadap PAD Kabupaten Indragiri Hulu dapat dilihat melalui grafik indeks pertumbuhan kontribusi dibawah ini.

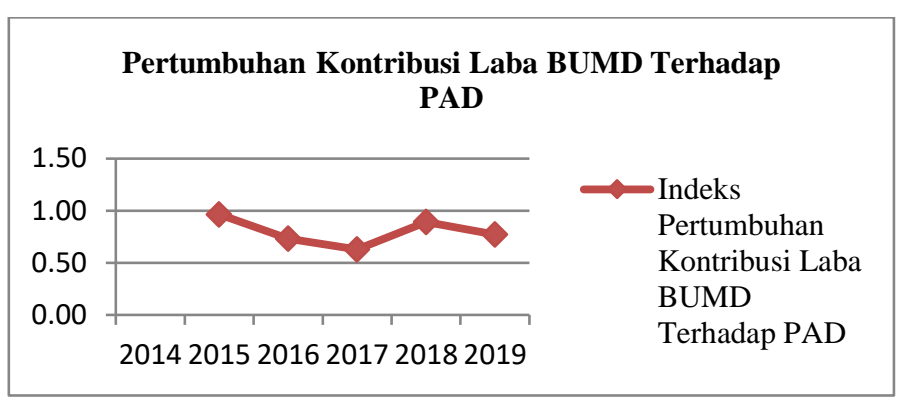

(Sumber : Bapenda Kabupaten Indragiri Hulu, Data diolah)

Gambar 2:

Pertumbuhan Laba BUMD Terhadap PAD Kabupaten Indragiri Hulu Tahun 2014 - 2019. Gambar 2 memberikan memperjelas perumbuhan kontribusi laba BUMD terhadap PAD Kabupaten Indragiri Hulu adalah fluktuatif dengan pembanding tahun 2014 sebagai tahun dasar, pertumbuhan tererndah pada kurun 2016-2017, pertumbuhan tertinggi adalah pada tahun 2018 kemudian pada tahun 2019 kembali menurun.

\section{Kontribusi Komponen PAD}

Untuk melihat sebarapa tinggi atau rendahnya laba BUMD dalam memberikan kontribusi terhadap PAD perlu Pertmembandingkan kontribusi komponenkomponen lain pembentuk PAD sehingga 0,97seberapa baik peran laba BUMD 0,73 berkontribusi terhadap PAD dapat ${ }_{0,89}^{0,63}$ dilakukan penilaian secara lebih rasional. 0,77

\section{Tabel 7}

Kontribusi Komponen Pendapatan Asli Daerah Kabupaten Indragiri Hulu Tahun 2014 - 2019.

\begin{tabular}{|c|c|c|c|c|}
\hline Tahun & $\begin{array}{l}\text { Pajak } \\
\text { Daerah }\end{array}$ & $\begin{array}{c}\text { Retribusi } \\
\text { Daerah }\end{array}$ & $\begin{array}{l}\text { Laba } \\
\text { BUMD }\end{array}$ & $\begin{array}{l}\text { Lain- } \\
\text { Lain } \\
\text { PAD } \\
\text { Yang } \\
\text { Sah }\end{array}$ \\
\hline 2014 & 0,19 & 0,10 & 0,017 & 0,69 \\
\hline 2015 & 0,28 & 0,08 & 0,016 & 0,62 \\
\hline 2016 & 0,25 & 0,10 & 0,012 & 0,64 \\
\hline 2017 & 0,20 & 0,03 & 0,010 & 0,77 \\
\hline 2018 & 0,37 & 0,04 & 0,015 & 0,57 \\
\hline 2019 & 0,31 & 0,03 & 0,013 & 0,76 \\
\hline \multicolumn{3}{|l|}{ Rata- } & 0,014 & 0,67 \\
\hline $\begin{array}{l}\text { Sumber } \\
\text { diolah) }\end{array}$ & Bapenda & Kabupaten & Idragiri & \\
\hline \multicolumn{5}{|c|}{$\begin{array}{l}\text { Komponen yang memberikan kontribusi } \\
\text { paling besar terhadap penerimaan }\end{array}$} \\
\hline
\end{tabular}


Lain-Lain PAD Yang Sah yang berkontribusi rata-rata $67 \%$ disusul komponen pajak daerah dengan sumbangan rata-rata sebesar $27 \%$ persen, di ikuti oleh retribusi daerah yang memberikan kontribusi sebesar 6,3\% persen, sedangkan laba BUMD hanya memberikan kontribusi terhadap PAD Kabupaten Indraggiri Hulu rata-rata sebesar 1,4\% yang merupakan sumbangan atau kontribusi terkecil terhadap PAD bila di bandingkan dengan komponenkomponen PAD lainya.

\section{Analisis Manajemen BUMD}

Manajemen adalah proses penyelesaian sesuatu dengan dan melalui orang lain secara efektif dan efisien (Robbins, 2018). Keberadaan ilmu manajemen menungkinkan sumber daya dalam organisasi dapat diatur dan dikelola dengan baik dan benar. Perencanaan, Pengorganisasian, Pelaksanaan dan Pengawasan merupakan fungsi-fungsi manajemen yang digunakan untuk mengelola kegiatan dalam organisasi secara terencana dan terarah (Nugroho, 2017). Sebagai perusahaan, BUMD sudah seharusnya dikelola secara profesional dan sesuai dengan prinsip-prinsip good corporate governance serta sesuai dengan tujuan revitalisasi BUMD, strategi pengelolaan BUMD sangat diperlukan sebagai upaya memaksimalkan kemampuan internal dalam mengambil peluang yang ada, dan menyikapi juga mengatasi ancaman dari eksternal. Setelah dilakukan reduksi data hasil wawancara, permasalahan-permasalahan manajemen BUMD Kabupaten Indragiri Hulu dapat rangkum dalam tiga permasalahan utama yaitu:

1. Sistem Manajemen Internal

Sistem manajemen masih birokratif telah mengurangi kemampuan dan kecepatan individu tim manajemen dalam berakselerasi, kurang kreatif dan inovatif dalam mengembangkan visi yang sesuai dengan kondisi kekinian, manajemen yang masih bernuansa birokratif melemahkan kemampuan internal untuk berkonsentrasi pada usaha yang berprospek tinggi, melemahkan upaya memperluas pasar dengan mempertahankan dan mencari pelanggan baru, serta melemahkan kemampuan dalam mengembangkan teknik atau strategi usaha baru yang dapat meningkatkan efisiensi dan efektifitas usaha.

2. Kemampuan Menyikapi dan Mengatasi Ancaman.

Kurangnya perhatian pada mutu produk dan jasa, kurang perhatian pada peningkatkan kompetensi SDM, minimnya kreativitas dan keaktifan tenaga pemasaran dalam mencari terobosan baru, belum memaksimumkan upaya dalam mengambil peluang usaha melalui upaya kerjasama yang saling menguntungkan dengan perusahaan sejenis atau stekeholder lain.

3. Perencanaan Strategis Perusahaan.

Manajemen BUMD belum secara optimal mengembangkan core business yang berprospek pada saat ini dan pertumbuhan perusahaan yang berkelanjutan.

\section{Simpulan}

Realisasi PAD menunjukkan hasil yang positif, namun capaian positif dari target PAD Indragiri Hulu periode 20142019 bukan hasil yang menggembirakan, karena secara rata-rata pertumbuhan realisasi PAD lebih kecil dari target yang direncanakan dan realisasi PAD terutama pada kurun waktu 2018-2019 terjadi penurunan dibanding periode 2017.

Secara rata-rata, target laba BUMD cenderung menurun atau rata-rata turun sebasar $-67 \%$, dan hal tersebut senada dengan realisasi PAD yang secara rata-rata juga menurun atau tumbuh minus sebesar $3,7 \%$, dan rasio efektifitas laba BUMD 
pada periode 2014-2019 rata-rata sebesar $7,4 \%$ persen atau masuk dalam kategori Kurang Efektif.

Nilai kontribusi laba BUMD terhadap PAD selama periode 2014 - 2019 secara rata-rata sebesar $1,4 \%$ persen, nilai ini menunjukkan bahwa kontribusi laba BUMD selama kurun waktu tersebut masih juga masuk pada kategori sangat kurang, dan laba BUMD hanya memberikan kontribusi terhadap PAD rata-rata sebesar $1,4 \%$ yang merupakan sumbangan atau kontribusi terkecil terhadap PAD bila di bandingkan dengan komponen-komponen PAD lainya.

Upaya untuk meningkatkan efektifitas dan peran BUMD dalam memberikan kontribusi terhadap PAD dapat dilakukan dengan mengurangi porsi birokratif pada dan dengan memperbaiki sistem manajemen internal BUMD yang lebih ramping dan adaftif sesuai dengan kebutuhan, menyikapi dengan bijak ancaman dari eksternal dengan memberikan perhatian pada mutu produk dan jasa, membuat terobosan baru dan secara intensif menjalin jejaring kerjasama usaha dan membangun jejaring dengan berbagai stakeholder yang dibutuhkan dalam rangka memperoleh pemahaman yang lengakap tentang pasar dan peluang dan kemampuan beradaptasi terhadap tantangan. Pertumbuhan dan keberlanjutan usaha BUMD dengan arah dan proyeksi yang lebih jelas harus menjadi fokus dalam membuat dan menetapkan rencana strategis. BUMD dapat eksis dan dikatakan tumbuh jika perusahaan daerah itu berhasil meningkatkan antara lain, meningkatnya volume penjualan, meluasnya pangsa pasar, meningkatnya besaran laba dan aset perusahaan dan berkembangkan jenis produk dan layanan, juga kemampuan membangun jejaring dan kerjasama pada lini bisnis maupun diluar lini bisnis yang sedang digeluti.

\section{Daftar Pustaka}

Andi Rustandi (2020), Efektifitas Investasi Perusahaan Daerah Pasar Resik Kota Tasikmalaya. Jurnal Ilmu Ekonomi Vol. 1, No.1, Universitas Siliwangi.

Anonim. 2010. P2 LIPI, 2010 Revitalisasi BUMD Dalam Perekonomian Daerah Lembaga Ilmu Pengetahuan Indonesia.

Dian A. Nogroho (2017). Pengantar Manajemen untuk Organisasi Bisnis, Publik dan Nirlaba. Penerbit; UBPress, Malang.

Halim Abdul, dan Muhammad Syam Kusufi. (2014). Akuntansi Keuangan Daerah. Edisi 4.Salemba Empat, Jakarta.

Heince J., Vekie A., Debby Ch. (2019) Analisis Kontribusi Badan Usaha Milik Daerah (Bumd) Terhadap Pendapatan Asli Daerah Kabupaten Sulawesi Utara (Studi Di PT. Bank Sulutgo). https:// ejournal. unsrat. ac.id/index. php/jpekd/ article/ view File/32776/30969.

Kasmir. 2010.Dasar-dasar Perbankan. PT.Raja Grafindo Persada. Jakarta.

Kresno Sarosa P. (2010). Kinerja dan Strategi Pengembangan Badan Usaha Milik Daerah (BUMD). Jurnal Ilmu Ekonomi dan Pembangunan Vol. 9, No. 1, Fakultas Ekonomi UNS.

Luigi, L. D., Vecky, A. J,. \& Patrick. (2017). Analisis Pendapatan Asli Daerah Kota Jayapura. Jurnal Berkala Ilmiah Efisiensi, 17 (01):22-33.

Maskun, Suwardi, Eko Prasetyo (2018)

Efisiensi Teknis Badan Usaha Milik

Daerah (BUMD) Bidang Jasa

Produksi Kabupaten Jawa Tengah.

Jurnal Ekonimi \& Studi Pembangunan Vol. 19, No. 1, Fakultas Ekonomi, Universitas Negeri Semarang.

Maria, Agnes 2004. Analisis Perkembangan Pendapatan Pajak Daerah Prediksi Pendapatan Pajak Daerah Serta Potensi Pendapatan Pajak Daerah. Skripsi. Yogyakarta : Universitas Sanata Dharma. 
Nurmiati, Fina Diana, Murhayani (2019). Kontribusi Badan Usaha Milik Daerah Terhadap Pendapatan Asli Daerah Kota Makassar. Seminar Nasional Fakultas Ekonomi Universitas Patria Artha.

Peraturan Pemerintah No. 54 Tahun 2017 tentang Badan Usaha Milik Daerah.

Robbins Coulter (2018). Manajemen Jilid 2 Edisi 13. Penerbit; Erlangga, Jakarta.

Undang-undang No. 33 Tahun 2004 tentang Perimbangan Keuangan antara Pemerintah dan Pemerintahan Daerah.

Undang-undang No. 23 Tahun 2014 tentang Pemerintahan Daerah.

Usman F. Julius A. Charly. M (2015) Analisis Efektifitas Dan Kontribusi Hasil Pengelolaan Kekayaan Daerah Yang Dipisahkan Terhadap Pendapatan Asli Daerah (Pad) Kabupaten Indragiri Hulu. Jurnal Kajian Ekonomi dan Keuangan Daerah Fakultas Ekonomi dan Bisnis Universitas Cendrawasih..

Yudho Taruno Muryanto, djuwityastuti (2014). Model Manajemen Badan Usaha Milik Daerah (Bumd) Dalam Rangka Mewujudkan Good Corporate Governance. Yustisia Vol. 3 No. 1 Januari - April 2014.

\section{PROFIL SINGKAT}

Heriasman ST. MT. Lahir 8 Februari 1969. Menyelesaikan pendidikan sarjana (S1) Universitas Diponegor pada Jurusan Planologi, pendidikan Sarjana Strata Dua (S2) di Universitas Gajah Mada jurusan Perencanaan Kota dan Daerah. Saat ini aktif sebagai dosen di Sekolah Tinggi Ilmu Ekonomi Indragiri (STIE-I) Rengat mengampu mata kuliah Manajemen Pembangunan Daerah dan Perencanaan Pembangunan.

Suwaji, SE. MM. Lahir 22 September 1974 Menyelesaikan pendidikan sarjana (S1) di Sekolah Tinggi Ilmu Ekonomi Indragiri (STIE-I) Rengat Program Studi Manajemen, pendidikan Sarjana Strata Dua (S2) di Universitas Muhammadiyah Yogyokarta (UMY) pada program Studi Manajemen. Saat ini aktif sebagai dosen di Sekolah Tinggi Ilmu Ekonomi Indragiri (STIE-I) Rengat pada mata kuliah Ekonomi Manajerial dan Analisis Laporan Keuangan. 